\title{
Cognitive and Metacognitive Aspects of the Development of Lifelong Learning Competencies in Law Students
}

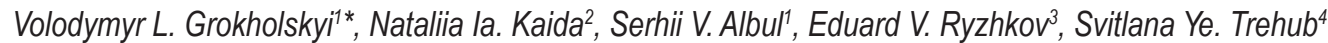

\author{
${ }^{1}$ Odesa State University of Internal Affairs, Odesa, Ukraine; e-mail: ihorkopotun@gmail.com; 1918phd@gmail.com \\ ${ }^{2}$ Kyiv University of Law of the National Academy of Sciences of Ukraine, Kyiv, Ukraine; \\ e-mail: natalia.teaching1979@gmail.com \\ ${ }^{3}$ Dnipro State University of Internal Affairs, Dnipro, Ukraine; e-mail: ok228b@gmail.com \\ 4Zaporizhzhia State Medical University, Zaporizhzhia, Ukraine; e-mail: phd1717@yahoo.com
}

\begin{abstract}
Lifelong learning is one of the main trends in educational and social policy in Europe, aimed at ensuring professional realization and social integrity of an individual. The article describes cognitive and metacognitive aspects of the formation of learning competence, as well as predisposition of law students to lifelong learning. A survey of 218 students and masters was conducted, data on the most popular and effective forms of knowledge acquisition (experience of formal, nonformal and informal learning over the past year), plans for further education and career development were collected. The dynamics of learning at different years of study is described. A group of students with pronounced learning and focus on lifelong learning ( $45 \%$ of the sample) was identified. A comparative analysis of two samples was carried out and qualities that could be considered markers of the LLL orientation were identified: a high level of metacognitive knowledge and metacognitive activity, reflective competence (at the cognitive, metacognitive and personal level), internal involvement in learning, focus on achieving professionalism and personal development, general self-efficacy, the prevalence of progressive and creative motives over consumer ones. Conclusions are drawn about the predominant role of metacognitions and personality determinants in the formation of lifelong learning competency among students. Reflection aimed at recognizing one's own cognitive processes and understanding their contribution to personal development is the main mechanism for the formation of meta-cognitive abilities. The results obtained in the study determine the ways of pedagogical support and psychological intervention to ensure the development of lifelong learning competencies in different categories of students.
\end{abstract}

Keywords: lifelong learning, educational competence, cognitive abilities, metacognitive competencies, reflection, individual's self-development.

\section{Introduction}

Lifelong learning (hereinafter - "LLL") is one of the main trends in modern educational, social and international politics. The concept of lifelong learning was introduced back in the 70's of the XX century under the auspices of UNESCO as the most effective way to solve the problems of professional mobility and the integration of some socially vulnerable groups: elderly people, forced and voluntary migrants, etc. (Lengrand, 1970; Faure et al., 1972). The past decades have confirmed the validity of this model (OECD, 2006). Numerous scientific studies by European scholars have clarified that formal and nonformal learning positively affects economic performance, social capital, psychological well-being, health, family relationships, and other areas of life (Delors, 1996; Schuller et al., 2004; Hammond and Feinstein, 2006; Aspin et al., 2012; Bogavac, D. and Đukić, T. M., 2017; Popovic et al., 2019; Boceliuk, 2020 and others). The global challenges of a post-industrial society (technological innovation, digitalization, information overload, demographic shifts, regular economic and social crises) put LLL among the necessary conditions for the existence of any person, regardless of age or profession.

In 2000, significant Memorandum on Lifelong Learning was adopted, which finally approved the entry of European society into the era of knowledge. Obviously, a successful transition to a knowledgebased economy and society must be accompanied by a transition to lifelong learning and in the full diversity of learning contexts. LLL is defined as "all purposeful learning activity, taken on an ongoing basis with the

\footnotetext{
"Corresponding author: ihorkopotun@gmail.com
} 
aim of improving knowledge, skills and competence" and is proclaimed a leading principle of education (Commission of The European Communities, 2000). The importance of the LLL concept for the state and society is determined by two main goals: first, this is the solution to the problem of unemployment, increasing economic potential by expanding employment opportunities and free entrepreneurship; second, it is a struggle against social exclusion and the formation of civic engagement in a joint activity and various social ties, involvement, desire and ability to "take life in one's own hands". The importance of LLL for an individual consists in personal self-realization: satisfying important cognitive and spiritual needs, developing abilities, improving the quality of life.

The $21^{\text {st }}$ century has fundamentally changed the traditional models of learning, communication and work - and they continue to change every day. The new era is called VUKA-world (volatility, uncertainty, complexity, ambiguity), it is a world that cannot be predicted (Mack et al., 2016). Under such conditions, the role of LLL in ensuring the ability of a person to quickly and effectively respond to inevitable changes in external conditions is growing. Such a path should begin with a high level of basic education and access to new competencies at any age. These goals are declared by the United Nations (2015) as the main guidelines for the sustainable development of man-kind until 2030.

In 2006, the European Commission launched the process of regularly reviewing the key competencies of The European Reference Framework of Key Competences for Lifelong, a regularly updated list of recommendations on investment in education that will help students gain the necessary knowledge and skills in the modern competitive world. In addition to knowledge and skills, an important educational product is proclaimed an attitude - a set of values, thoughts and beliefs; "disposition and mindsets to act/react to ideas, persons or situations" (European Commission, 2018). The list contains eight equally important competencies, which together constitute the key to empowerment: communication in the mother tongue and foreign languages; mathematical competence and basic competences in science and technology; digital competence; learning to learn; social and civic competences; sense of initiative and entrepreneurship; cultural awareness and expression (European Parliament and Council of the European Union, 2006). In addition to this list, the so-called "transversal skills" are important reference points - the qualities necessary for success regardless of cognitive abilities and professional skills: problem solving, risk assessment, initiative, decisiontaking, constructive management of feelings, critical thinking, creativity (Siarova, Sternadel and Mašidlauskaitè, 2017). The latest edition of the Reference Framework proclaims the need to find new ways of learning in a society that is becoming increasingly mobile, ensuring the right mix of "hard" and "soft" skills (European Commission, 2018).

Among the "soft skills", the learning to learn competency seems to be especially important - it is a transversal element that provides all other competencies. Its significance is justified by the following forecast: "Most children entering primary school today will end up working in completely new job types that do not yet exist, and half of today's work activities could be automated by 2055" (European Commission, 2018). The Reference Framework defines the learning to learn competency as to pursue and persist in learning, to organize one's own learning both individually and in groups. This competence includes effective management of time and information, awareness of one's learning needs, identifying available opportunities, as well as sufficient positive motivation and confidence to overcome obstacles for successful learning. The cognitive aspect of academic competence means the acquisition, processing, assimilation and application of new knowledge and skills based on previous experience, as well as seeking and making use of guidance (European Parliament and Council of the European Union, 2006). In terms of psychological terminology, all these aspects can be defined as metacognition - knowledge of one's own thinking processes and strategies, the ability to consciously reflect them, and to carry out actions based on this knowledge (Flavell, 1979).

Although the LLL model is more often associated with adult education, we consider it important to study younger groups, in the periods of formation of the foundations of cognitive and metacognitive competencies. The stage of learning at the university is especially important when a person moves from externally regulated cognitive activity to independent and self-regulated learning. At this time, the person's LLL orientation is fully manifested for the first time - internal orientation and behavioural activity aimed at maximizing the use of opportunities to improve one's knowledge, skills and competencies in a particular life situation in view of personal, social and professional prospects.

In recent years, the understanding of learning competence has been less and less focused on the self-organization of learning and career, and is included in the wide context of personal development (awareness, understanding of the self, taking care of one-self, self-management, independence, drive, sense of initiative and social interrelations (communication, cooperation and teamwork, negotiation, conflict resolution, respect and responsibility, empathy and inclusion). In addition to those already mentioned, the new approach includes some new tasks as resilience, ability to deal with uncertainty persistence and 
complexity (European Commission, 2018).

National education systems quickly reoriented their goals and standards in the context of the LLL concept. First of all, there was a shift from a socially-oriented model of qualifications to a personalityoriented model of competencies (Raven, 2002; Barros, 2012). Today, the priority is not the assimilation of a ready-made set of knowledge and skills by students, but the formation of learning competence, that is, the ability to independently determine their need for knowledge, obtain and assimilate the necessary information, and apply it in different life situations. The leading role in cognition belongs not to the state or educational institution, but to the individual himself. It is important to understand that no knowledge in the modern world is stable or final. Any person needs to be ready to change their existing ideas and habitual methods of action, to finish their studies along the way. The offer of educational services of various formats and quality has grown significantly, which requires critical reflection.

In this context, the experience of Ukrainian experts in the field of law is particularly interesting, since it is gained in unique conditions (which can be called the standard of the VUCA world). The fact is that the legal framework in Ukraine is extremely dynamic and unpredictable. Over the past 30 years, three revolutions have occurred and regimes have changed dramatically. Reforms of all spheres of life are continuous, although they are not very streamlined and effective. In 2019, the new government proclaimed the socalled "turbo-regime" of work in the country's main legislative body and the next accelerated reforms in many social and economic spheres. Legal experts are the first to respond to a change in the "rules of the game": the introduction of new regulations and their implementation in existing laws. They are forced to quickly adapt to turbulent, often contradictory, innovations, ensuring the efficient operation of state authorities, individuals and legal entities, resolving conflicts in accordance with the law, monitoring compliance with obligations and ensuring the rights and freedoms of the whole society.

The objective of this study is to identify cognitive and metacognitive aspects of the development of educational competencies, as well as LLL orientation (predisposition of law students to lifelong learning).

This work will allow moving on to more general patterns of the development of learning competencies of students in the context of the LLL model. It can serve as a scientific, theoretical and methodological justification for the activities of corporations, public organizations, private and public educational institutions to ensure affordable adult education.

\section{Materials and methods}

\section{Sample description}

The empirical study involved 218 volunteers - students of $2^{\text {nd }}-4^{\text {th }}$ years of study and master's programs $\left(5^{\text {th }}-6^{\text {th }}\right.$ years of study) in the specialties "Law" and "Judicial Proceedings" of several Ukraine universities (Odesa State University of Internal Affairs, Kyiv University of Law of the National Academy of Sciences of Ukraine and Dnipro State University of Internal Affairs). The age of respondents is 18-36 years (average age 21.4); balanced distribution by gender (46.3\% of women, $53.7 \%$ of men). Most students $(68.1 \%)$ study for fee, which gives us reason to assume a conscious choice of profession and interest in further practical application of the knowledge and skills. $35.2 \%$ of respondents combine studies with work.

\section{Data collection methodology}

The study was held in 2018-2020. Despite the scientific urgency and practical relevance of the topic, there are still no reliable diagnostic methods for diagnosing LLL competencies. Some authors rely on data from questionnaires on the study of "readiness for self-education and self-development," but the psychometric qualities of such tools are questionable.

Therefore, the main criterion in our study was life dates - real events in the lives of students that confirm their readiness for LLL (collection of biographical information). We asked students to recall and describe their studies over the past year in the most detailed way possible. During the year, students go through a full educational cycle, which includes two academic semesters and several vacation periods. On the one hand, the individual characteristics of educational activities are fully manifested during this period, even taking into account different life situations. On the other hand, this is a period that the student remembers well and with respect to which reliable information can be obtained. The experience of obtaining knowledge in three categories according to Eurostat (2016) was recorded - formal education, nonformal education, informal education. The respondents assessed how much the experience gained 
was useful in their life (professional development, social interaction, self-knowledge, self-development, etc.). Students completed the form shown in Table 1.

\section{Table 1}

Questionnaire form on individual experience of LLL

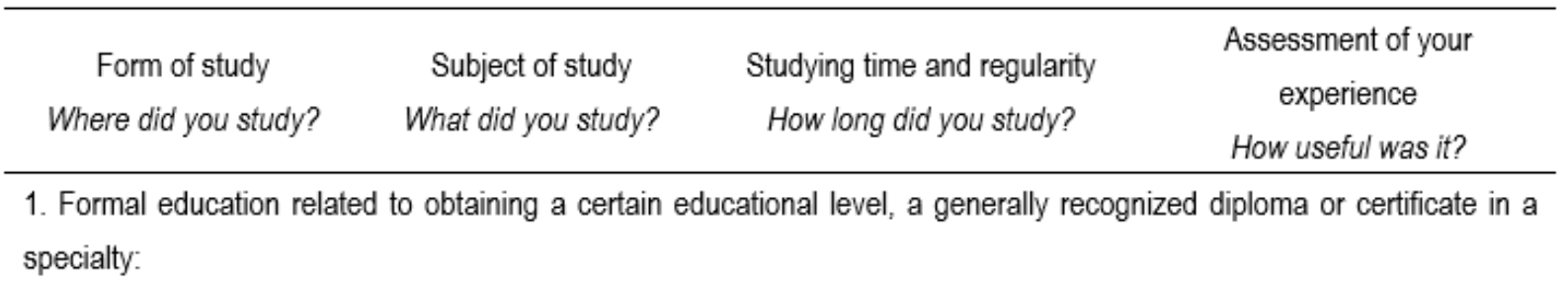

2. Nonformal education (occurs in parallel with your main education and does not result in obtaining an officially recognized document: training courses, seminars, master classes, circles, trainings, individual lessons with a tutor, etc.):

3. Self-study without the participation of teachers (initiated by you, your social environment or occurs spontaneously).

\section{Please indicate your plans for further education, if any:}

Real experience of activity in the three main forms of education, information on the applicability (usefulness) of the knowledge and skills gained, as well as on the plans for further self-education of respondents, allow us to interpret the data as a measure of LLL orientation and study the specifics of this phenomenon in the years of studentship.

The results of a biographical survey are presented in the form of phenomenological descriptions; Frequencies of popular response categories were also calculated. An analysis of the real experience of educational activity allowed identifying and concretizing the criteria for LLL orientation of student. On this basis, the sample was divided into two groups:

- LLL-oriented students with diverse, regular and useful experience of formal, informal, independent study (six or more cases over the past year), which is accompanied by developed educational prospects - 98 people;

- Ordinary students who do not demonstrate pronounced activity in obtaining knowledge and do not have plans for further education, in addition to formal education at the university in the chosen specialty -120 people.

As for the selected groups, a comparative analysis was conducted on a number of quantitative indicators (age, academic performance, data from standardized diagnostic tests and questionnaires):

1. To determine the cognitive aspects of the development of the LLL competency, we collected data on the academic success of students - average rating score for the last two semesters.

2. General intelligence was measured using Raven's Progressive Matrices - a classic test that allows measuring the " $g$ " factor using non-verbal tasks of increasing complexity (determining the relationship between abstract figures). The test was carried out in group form with a time limit of 20 minutes, the total number of correct answers was recorded (Mukhordova and Shreiber, 2011; Raven, Raven and Kurt, 1997).

3. The questionnaire for self-assessment of metacognitive knowledge and metacognitive activity was developed by Skvortsova (2005) and Kashapov (2012) in line with the concept of metacognition of Flavell (1979). The methodology allows one to evaluate both the main components of metacognition: metacognitive knowledge and metacognitive activity, as well as a number of additional characteristics: concentration, acquisition of information, choice of main ideas, time management (Kashapov, 2012).

4. The methodology "Reflexive skills" by Savchenko (2016) presents a competency-based approach to reflection as "a phenomenon that is formed and developed in the system of reflexive experience, providing the realization of reflexivity as a general ability of the individual and determining the level of his/her competence in various activities through awareness and reorganization of personal experience". Three sets of questions allow evaluating the level of development of reflective competence at different levels: cognitive, metacognitive and personal reflective skills. The total indicator of three subtests reflects the general level of development of students' reflexive experience. 
5. The questionnaire of implicit theories is a modification of Dweck's methods made by Kornilova et al., (2008). It allows diagnosing students' everyday ideas about the possibilities of developing intelligence and personal growth in the learning process. In addition to the three K. Dweck's scales reflecting implicit ideas about intelligence, personality and learning objectives, the developers added the Self-assessment of Learning scale as a predictor of students' academic performance (Kornilova et al., 2008).

Some generally recognized psychological factors that determine the learning activity of students and can affect the formation of cognitive competences of LLL at this stage of life were also diagnosed.

6. The methodology for diagnosing the motivational structure of an individual of Milman, V. E. (2005), developed in line with the humanistic theory of needs of Maslow, allows identifying and evaluating seven types of personality orientation, located in the continuum from consumer, regressive to productive, progressive dispositions.

7. The scale of general self-efficacy of Ralf and Matthias (Schwarzer, Erusalem and Romek, 1996), allows evaluating a person's conviction in the effectiveness of his/her own actions as a stable personal characteristic.

All diagnostic tools have confirmed validity and reliability, are standardized on representative samples. They are published in open sources and recommended for use for scientific purposes.

The statistical package SPSS for Windows (version 16.0) was used when processing the data. Normality of data distribution was verified using the Kolmogorov-Smirnov Test. Since the distribution of some parameters differed from normal, we used the nonparametric method - the Mann-Whitney U-Test - for comparative analysis. Qualities in which the most striking differences between the groups were manifested can be considered prerequisites and markers of the LLL orientation.

\section{Results}

\section{General analysis of student learning activity}

On average, the respondents indicated 5-8 specific forms and methods of training that took place in their life during the year (the maximum value in the sample is 15 , the median value is 6 ). The survey results give us a general idea of the forms and methods of obtaining knowledge that students use at different stages of their study - Table 2.

\section{Table 2}

Individual experience of LLL in law students, \%

\begin{tabular}{|c|c|c|c|c|c|}
\hline \multicolumn{2}{|c|}{ Categories and answers: } & \multirow{2}{*}{$\begin{array}{c}2^{\text {nd }} \\
\text { year } \\
\mathrm{N}=67\end{array}$} & \multirow{2}{*}{$\begin{array}{c}3^{\text {rd }} \\
\text { year } \\
\mathrm{N}=60\end{array}$} & \multirow{2}{*}{$\begin{array}{c}4^{4^{\text {th }}} \\
\text { year } \\
\mathrm{N}=63\end{array}$} & \multirow{2}{*}{$\begin{array}{c}5^{\text {th }}-6^{\text {th }} \\
\text { year } \\
\mathrm{N}=28\end{array}$} \\
\hline & & & & & \\
\hline 1. Formal & first higher education & 98.51 & 98.33 & 96.83 & 82,14 \\
\hline \multirow[t]{4}{*}{ education: } & second higher education & 1.49 & 1.67 & 3.17 & 17,86 \\
\hline & $\begin{array}{l}\text { parallel study for another specialty at the univer- } \\
\text { sity }\end{array}$ & - & 3.33 & 4.76 & 7,14 \\
\hline & certified training courses & 2.99 & 3.33 & 6.34 & 10,71 \\
\hline & certified online courses & 4.45 & 8.33 & 11.11 & 3,57 \\
\hline 2. Nonformal & webinars & 58.21 & 73.33 & 63.49 & 71,43 \\
\hline \multirow[t]{4}{*}{ education: } & master classes & 2.99 & 6.67 & 15.87 & 35,71 \\
\hline & open lectures & 59.70 & 65.00 & 23.81 & 17,86 \\
\hline & corporate trainings, seminars & - & 3.33 & 9.52 & 21,43 \\
\hline & individual sessions & 5.97 & 6.67 & 6.34 & 7,14 \\
\hline \multirow[t]{6}{*}{$\begin{array}{l}\text { 3. Self- } \\
\text { study: }\end{array}$} & $\begin{array}{l}\text { search for necessary information on Internet } \\
\text { resources }\end{array}$ & 89.55 & 91.67 & 85.71 & 89,29 \\
\hline & viewing video materials & 74.63 & 71.67 & 64.66 & 64,28 \\
\hline & studying books by specialty & 53.73 & 63.33 & 61.90 & 82,14 \\
\hline & $\begin{array}{l}\text { study of relevant information in professional } \\
\text { journals }\end{array}$ & 14.93 & 25.00 & 26.98 & 53,57 \\
\hline & professional practice in parallel with study & - & 6.67 & 15.87 & 64,28 \\
\hline & $\begin{array}{l}\text { analysis and discussion of life situations from a } \\
\text { legal point of view }\end{array}$ & 20.90 & 26.67 & 36.51 & 71,42 \\
\hline \multicolumn{2}{|c|}{ 4. Future educational paths planned } & 11,94 & 26.67 & 38.10 & 85.71 \\
\hline
\end{tabular}


The sample is made up of full-time students who undergo basic professional training at universities therefore, formal education is presented in $100 \%$ of respondents. Some of them already have a diploma in another specialty and receive a second higher education. But this percentage is extremely low (one or two students per the year), since working adults prefer to study by correspondence or distance learning. The Ukrainian education system allows you to get a second diploma in a master's program; five respondents took this opportunity, which makes up $17.86 \%$ of masters. Parallel study in two different specialties at the university is associated with a very high academic load, there are few such students.

In addition to traditional forms of formal education, different training courses were demanded among students, which result in obtaining diplomas or certificates.

This activity increases by the $4^{\text {th }}$ and $5^{\text {th }}$ year of study - when students already understand what professional competencies they need for better employment. Some of these courses are offered by local universities or private service providers - they are popular with master students. In early years, distance learning on Ukrainian and international online platforms (Coursera.org, Prometheus.org.ua, etc.) is much more popular. Most students are attracted by the opportunity to learn foreign languages - more than $90 \%$ of students indicated this as their main goal or additional positive effect.

Nonformal education is represented by a wide range of different events that the modern educational services market is rich in. As in the previous case, the most popular was online training, with more than $70 \%$ of respondents resorted to during the year. Moreover, more than a third of cases have

nothing in common with the professional field - law. Using informal learning methods, young people learn foreign languages, comprehend modern art, and penetrate into the pressing general humanitarian problems of mankind. They acquire knowledge and practical skills in the most diverse and unexpected areas: sports and a healthy lifestyle, psychology, marketing, self-promotion, photography, art, cooking and much more.

Junior students prefer affordable ways of learning: free, short-term, with a free form of access and attendance. Many attend open lectures of opinion leaders on legal and humanitarian issues (such events are regularly organized by the university). Masters prefer master classes, where they can personally familiarize themselves with the practical experience of reputable experts. Corporate resources - trainings and seminars that are directly related to current work tasks - are available for respondents who are already working in their specialty.

As we can see from Table 2, the demand for nonformal forms of education is growing along with the age and educational experience of students.

All students without exception noted that one way or another they study independently without the participation of teachers (informal learning). Most often, they look for the necessary information on Internet resources: watch videos on YouTube and TED, read professional literature (books and periodicals), analyze and discuss current events from the point of view of the legal situation. In their third year of study at the university, students begin professional practice, where they test knowledge, skills and competencies they have gained.

An analysis of the answers to the question about the time spent for different forms of education showed that, on average, various forms of learning activity occupy about a third of students' temporary resource. The study load is 58 hours a week, this is exactly the same as that left for other forms of activity: communication, leisure, work, etc. In Figure 1, we included sleep time at the rate of 7.5 hours per day as the optimum for this age group. The data obtained are very averaged, since the scatter of individual indicators is quite large.

\section{Figure 1.}

The average time (hours per week) that students spend on different forms of learning activity.

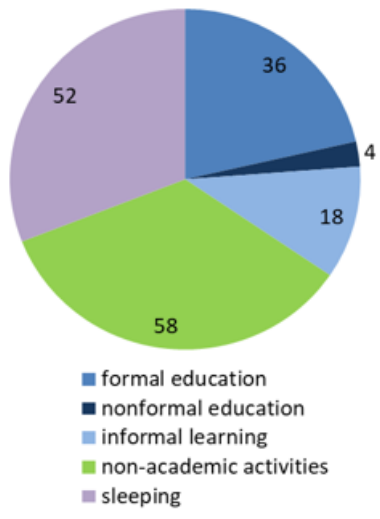

www.ijcrsee.com 
Lectures, seminars and workshops at the university are the most regular and long-term type of educational activity of students, it takes from 18 to 45 (on average 36) hours a week. Nonformal education is characterized by short-term duration - it is mainly 2-5-hour irregular events; students spontaneously attend what is in their area of their interest. Self-study is fairly regular. It accompanies formal learning activities and takes an average of 18 hours a week (data scatter is from 5 to 30 hours; this indicator is closely related to student performance).

It is interesting that non-formal learning was recognized as the most effective by students. $40 \%$ of the respondents indicated the extreme benefit and practical applicability of the experience. Subjective assessments of formal education ranged from extremely low to high. The noted advantages of studies at the university included: fundamental knowledge and the ability to directly contact teachers, receiving feedback. Most students recognized self-study as extremely ineffective. For them, this is only an additional, auxiliary element for consolidating the knowledge acquired at the university.

Interesting results were obtained regarding the dynamics of the development of curricula and prospects of students. The percentage of respondents who have an idea of their future and include different types of LLL is steadily increasing - from $11.94 \%$ in the second year to $85.71 \%$ among master students.

It turned out that it is difficult for most students to project and formulate their own educational trajectory. Most of the answers relate to formal learning: "finish my studies and get a good job", "continue studying in a magistracy", "get a scientific degree", etc. They do not plan to do an independent internship or practice related to building up professional experience. The survey showed that students quite often think about getting a second specialty (18 people indicated this, i.e. $8.26 \%$ of the total sample). These cases reflect disappointment in the chosen profession and/or the initial lack of educational motivation.

Additional study or improvement of a foreign language is planned more often than others among the methods and directions of nonformal education. But in general, students do not have clear plans for nonformal or independent education.

\section{Comparative analysis of samples and identification of the distinctive qualities of LLL-oriented students}

Based on the obtained data, we divided the students into two samples according to the criterion of the activity of learning. The sample we called "LLL-oriented" brought together students who:

1) indicated 6 or more diverse forms of gaining knowledge during the year (the median value of this indicator in the total sample);

2) along with formal education, used nonformal and independent forms of learning;

3) pointed out the benefit of the experience gained in various areas of their life;

4) formed positive learning prospects for the future.

There were 98 such people, i.e. $44.96 \%$ of the total sample. We considered the rest of the sample as a control group of "ordinary students". We assume that these students may show LLL activity in the future when life circumstances change, therefore, the data obtained reflect only the features of the student sample.

A comparative analysis of diagnostic parameters in the samples allowed us to identify the qualities that distinguish respondents with high academic competence and can be considered markers of the LLL orientation of university students - Table 3. 
Table 3.

Comparative analysis of samples of students with high and low learning activity

\begin{tabular}{|c|c|c|c|c|}
\hline Measured indicators: & $\begin{array}{l}{ }^{\text {"Ordinary stu- }} \\
\text { dents }, N=120 \\
(M \pm S D)\end{array}$ & $\begin{array}{c}\text { ULL-oriented stu- } \\
\text { dents }{ }^{\circ}, \mathrm{N}=98 \\
(\mathrm{M} \pm \mathrm{SD})\end{array}$ & $\begin{array}{c}\text { Mann- } \\
\text { Whitney } \\
U\end{array}$ & $\begin{array}{c}\text { Significance } \\
\text { of the differ- } \\
\text { ences } \\
\text { p-level }\end{array}$ \\
\hline Age of students & $20.96 \pm 6.11$ & $21.85 \pm 5.93$ & 5343.5 & 0.245 \\
\hline $\begin{array}{l}\text { Academic performance (average rating for two } \\
\text { semesters) }\end{array}$ & $78.75 \pm 15.23$ & $83.12 \pm 20.4$ & 9523 & 0.094 \\
\hline $\begin{array}{l}\text { Raven's Progressive Matrices (2002) (\% of } \\
\text { correct answers) }\end{array}$ & $88.56 \pm 8.55$ & $92.41 \pm 7.56$ & 9641.5 & 0.127 \\
\hline \multicolumn{5}{|c|}{ Self-assessment of metacognitive knowledge and metacognitive activity (Skvortsova, 2005; Kashapov, 2012) } \\
\hline Metacognitive knowledge & $10.77 \pm 5.67$ & $12.16 \pm 3.92$ & 8166.5 & $0.001^{ \pm}$ \\
\hline Metacognitive activity & $7.15 \pm 3.84$ & $10.27 \pm 4.12$ & 7878.5 & $0.000^{*}$ \\
\hline Concentration & $2.10 \pm 1.02$ & $2.34 \pm 1.53$ & 10094 & 0.365 \\
\hline Ability to receive information & $3.88 \pm 1.65$ & $5.16 \pm 0.79$ & 8830.5 & $0.010^{*}$ \\
\hline Selection of key ideas (metacogritive goals) & $1.97 \pm 2.10$ & $2.83 \pm 0.83$ & 9527.5 & 0.096 \\
\hline Ability to manage fime & $4.03 \pm 0.91$ & $5.85 \pm 1.16$ & 9208.5 & $0.038^{*}$ \\
\hline \multicolumn{5}{|l|}{ Reflexive skills (Savchenko, 2016) } \\
\hline $\begin{array}{l}\text { The level of development of reflective experi- } \\
\text { ence }\end{array}$ & $414.0 \pm 30.7$ & $451.7 \pm 32.2$ & 3382.5 & $0.000^{ \pm}$ \\
\hline Cognitive reflective skills & $105.7 \pm 15.8$ & $112.5 \pm 14.8$ & 8765.5 & $0.007^{*}$ \\
\hline Metacognitive reflexive skills & $145.9 \pm 22.8$ & $158.2 \pm 26.3$ & 4781 & $0.000^{*}$ \\
\hline Personal reflexive skills & $162.4 \pm 20.9$ & $181.0 \pm 21.3$ & 4333 & $0.000^{*}$ \\
\hline \multicolumn{5}{|c|}{ Questionnaire of implicit theories and learning objectives of C. Dweck (Komilova et al., 2008) } \\
\hline Acceptance of the implicit incremental theory & $8.15 \pm 1.58$ & $8.27 \pm 1.35$ & 10235.5 & 0.466 \\
\hline $\begin{array}{l}\text { Acceptance of the implicit theory of "enriched } \\
\text { personality" }\end{array}$ & $2.05 \pm 1.63$ & $5.16 \pm 0.89$ & 8620.5 & $0.004^{*}$ \\
\hline Acceptance of learning goals & $1.24 \pm 3.42$ & $8.86 \pm 227$ & 4887.5 & $0.000^{*}$ \\
\hline Learning self-assessment & $5.10 \pm 2.11$ & $5.87 \pm 2.07$ & 9701 & 0.147 \\
\hline General self-efficiency scale & $27.16 \pm 3.20$ & $30.56 \pm 2.15$ & 7777.5 & $0.000^{*}$ \\
\hline \multicolumn{5}{|c|}{ Diagnostics of the motivational structure of personality (Milman, 2005) } \\
\hline - motivation for maintaining sustenance & $10.28 \pm 2.14$ & $6.40 \pm 3.25$ & 5661 & $0.000^{*}$ \\
\hline - motives of comfort and safety & $10.77 \pm 1.62$ & $7.35 \pm 2.39$ & 5840 & $0.000^{*}$ \\
\hline - prestige and status motivafion & $8.39 \pm 2.33$ & $8.77 \pm 2.45$ & 10366 & 0.581 \\
\hline - motivation for communication, joining a group & $12.60 \pm 2.80$ & $11.77 \pm 2.35$ & 9909 & 0.248 \\
\hline - motivation for general (business) activity & $7.58 \pm 3.12$ & $8.42 \pm 2.44$ & 9172 & $0.036^{t}$ \\
\hline - motivation for creative activity & $12.11 \pm 2.78$ & $13.45 \pm 3.20$ & 9334.5 & 0.067 \\
\hline - motivation to bring public benefit & $10.65 \pm 2.47$ & $13.89 \pm 2.21$ & 7870.5 & $0.000^{*}$ \\
\hline Progressive motivational profile & $29.44 \pm 5.16$ & $22.52 \pm 4.81$ & 4325 & $0.000^{*}$ \\
\hline Regressive motivational profile & $30.34 \pm 5.07$ & $35.76 \pm 5.18$ & 4915 & $0.000^{ \pm}$ \\
\hline
\end{tabular}

Note: * $p \leq 0.05$ confirms the statistical significance of the differences; in this case, the hypothesis $\mathrm{HO}$ is rejected and the hypothesis $\mathrm{H} 1$ is accepted - the group of LLL-oriented students exceeds the control group in terms of the severity of the sign. 
The average indicator of academic success in the sample of LLL-oriented students is slightly higher, but the difference does not reach the level of statistical significance $(p=0.094)$. The scatter of data for this indicator is very high; in both groups there are students with very high and low scores.

There were also no significant differences between the samples in the level of general intelligence measured using the Raven Matrices $(p=0.127)$. All students do quite well with non-verbal tasks, which indicates developed cognitive abilities.

The similarity of the groups was found on the scales of the Questionnaire of Implicit Theories and Learning Objectives. Law students are convinced of the possibility of developing, "building up" their intelligence in the process of cognitive activity $(p=0.466)$. Self-assessment of inclusion in the educational process is expressed in both samples at an average-positive level $(p=0.147)$ : in different situations, learning can give students pleasure or cause stress and anxiety. The level of metacognitive manifestations in groups also significantly differs. Summarizing the results, we note the distinguishing features of LLLoriented students.

- High self-assessment of the level of metacognitive knowledge $(p=0.001)$ : the functioning of one's cognitive processes (attention, memory, thinking), the ease of acquiring new knowledge and its application in various situations. High metacognitive activity $(p=0.000)$ is manifested primarily in the self-organization of cognitive activity, the development of self-regulation skills and management of their cognitive processes. LLL-oriented students have expressed ability to receive and store information $(p=0.010)$, the ability to effectively organize and distribute their time $(p=0.038)$.

The ability to choose metacognitive goals (main ideas) in this group is slightly higher, but the difference does not reach the level of statistical significance $(p=0.096)$. Most likely, this metacognitive ability is in the process of development. In the process of formal and non-formal learning, students acquire the skills of independently identifying information that is important for further study.

- The level of development of reflexive experience and a high level of reflexive competence $(p=0.000)$, i.e. the ability to "track" their mental and practical actions and analyse their correctness. The reflective skills of LLL-oriented students have advantages at all levels: 1) cognitive, which is manifested in the analysis of the existing knowledge system, its compliance with the requirements of the situation $(p=0.004) ; 2)$ metacognitive, when the student's mental activity is aimed at analysing and regulating their own intellectual activity ( $p=0.000) ; 3)$ personal, aimed at resolving internal contradictions in the process of self-knowledge, self-determination, self-projecting and self-development $(p=0.000)$.

- The prevalence of a progressive motivational profile $(p=0.000)$ with a pronounced focus on motivation for general (business) activity and the desire to bring public benefit, while the needs for maintaining sustenance and the motives for comfort/safety are much lower. LLL-oriented students are characterized by energy, orientation toward achievements, creation, understanding and cognition, the desire to realize the knowledge and skills gained in significant useful activities.

- One of the most expressive differences between groups relates to the acceptance of learning goals $(p=0.000)$. LLL-oriented students are much more focused not on quick results and good scores (performance goals), but on mastery of skills and the ability to learn something (learning goals). In this group, a degree of acceptance of the implicit theory of "enriched personality" is relatively high $(p=0.004)$. Unlike the control group, LLL-oriented students consider the learning process not only as a way to develop intelligence and achieve professional excellence, but also as a way to develop their personality in all its diversity. They are convinced that a person is a subject of personal growth, and they are confident that they can significantly affect their own personal characteristics. These internal ideas (subjective categorizations) affect the specifics of learning motivation and act as the main regulators of activity both in education and in other areas of life (for example, in relationships). Therefore, LLL-oriented students are not afraid to fail and are actively involved in situations with an uncertain outcome. They tend to "work on themselves" and are more tolerant of the failures and weaknesses of other people.

- Significantly higher self-efficacy $(p=0.000)$. LLL-oriented students are convinced that they are able to behave in such a way that will lead to the desired results. Confidence in one's abilities and belief in the success of one's actions stimulate active and conquering behaviour in a wide range of social, educational and professional situations.

A comparative analysis showed that differences in educational activity and LLL orientation are associated not so much with academic performance and cognitive abilities as with metacognitive characteristics and personal qualities of students. 


\section{Discussions}

The study contains a detailed statistical analysis of the forms of learning used by students at different stages of education. These data are essential for building a holistic educational policy and the practical organization of effective education for specialists based on the LLL principles. In Ukraine, such studies are just beginning to be carried out in different professional groups (Serbin and Kulyk, 2019; Bochelyuk, 2020). Their implementation is complicated by the lack of a unified measuring technique, which would make it possible to compare the results obtained and track their dynamics, as well as the lack of generally accepted criteria for the formation of LLL competencies. Data on the educational activity of law students are published for the first time; it is important to continue to study and detail these trends.

The dynamics of learning is noteworthy. The demand for additional formal and non-formal education is growing along with the age and educational experience of students. Young people are mostly immersed in their main activity and are not looking for sources of additional education. We understand that students are an actively learning social group; specially organized training is the main type of their activity, in which course personal and professional identities are formed. On the other hand, senior students and masters already have a job (sometimes a family), which reduces the overall educational activity, but makes it more focused.

Among adults who already have higher education and work experience, the most convenient and sought-after way to study is master's degree - a form of formal education that allows immersing in the academic environment, quickly getting a high-quality education and universally recognized qualifications. It was repeatedly noted in earlier studies of Ukrainian scholars that professional reorientation and retraining in adulthood not only expands a person's labour opportunities, but also allows changing his/ her life program: revising his/her own values (Tychyna, 2013), restoring lost identity (Symonchuk, 2000), solving age and personality crises (Bochelyuk and Panov, 2020).

The question remains open about the age structure of the identified clusters, which can be a significant influencing factor. It is expected that psychological and social maturity is an important prerequisite for independent student learning activity. But when comparing the samples, no significant differences in age were revealed. This result refers us to the well-known position that for adults, the stages of development of thinking, be-haviour and personality are determined not by the chronological framework, but by the circumstances of life and the cultural context - occupation, experience, goals, attitudes, etc. (Craig and Baucum, 2002). Studying the correlations between age (or rather, maturity of a person) and the characteristics of cognitive activity in the context of the LLL model is an important prospect for further research.

An important fact was revealed in the survey: students do not plan their educational path in advance. Learning outside the university develops spontaneously and rather chaotically. In addition, most students demonstrate a low level of reflection of their cognitive activity - they do not understand the contribution that different types of education make to their development, they do not realize their cognitive needs, they cannot determine their cognitive style and choose the type of educational load that suits them. This situation can be explained by the fact that students do not have sufficient experience - neither at school nor at the university can they independently choose or adjust curricula. In the traditional (formal) education system, Ukrainian students are still objects, not subjects of education.

Before graduation, students constantly need external guidance that would stimulate, guide and evaluate the effectiveness of their cognitive activities. Using the model of evolutionary development of Kegan (1982), we can define this stage of formation as "interpersonal", which is characterized by culture of mutuality, interpersonal concordance orientation and conformism. The "team game" stage is normal and natural for adolescents, but it should be remembered that more than fifty percent of adults never go beyond it (London, 2011). The next stages of the formation of "orders of consciousness", which we consider as a perspective of cognitive development, are "institutional", based on self-system identity and personal autonomy (a person becomes an author of his/her own life, independently realizing himself in his career and social environment) and "interindividual" - the highest stage of self-awareness and selfunderstanding, understanding the limits of his/her own system of principles (Kegan, 1982).

The main mechanism of personality formation in this model is self-reflection; our study confirmed the fundamental significance of this metacognitive ability. In addition, in recent studies Savchenko, Alexandrova and Oliinyk (2017) explained that the formation of reflexive competence determines the functioning of the experience system at the meta-cognitive level.

Differentiation of students according to the level of educational activity and LLL orientation allowed identifying a number of significant differences. It has been noticed that LLL-oriented students are distinguished not by cognitive abilities (academic performance and intelligence), but by motivational 
and personal characteristics: curiosity, orientation towards cognition of complex ideas and phenomena, prevalence of the motives of creation over the motives of storage. High learning activity of students is reliably associated with the level of development of meta-cognitive competencies: reflective skills, awareness of their cognitive abilities and limitations, the ability to receive and apply information, selforganization, self-regulation of cognitive processes, implicit theories and goals of learning. These data expand existing knowledge about the "soft skills" necessary for life success (Kautz et al., 2014; Field, 2012).

In the context of the latest Council Recommendation on Key Competences for LifeLong Learning, the listed qualities fall into two categories: personal (intrapersonal) competencies, i.e. self-awareness, self-government and other aspects that help regulate thoughts, emotions and behaviour in achieving goals, as well as learning (intellectual) competencies that help a person maintain activity in learning (European Commission, 2018). As the results showed, the cognitive, metacognitive, personal and behavioural aspects of LLL are closely interrelated and affect each other.

The definition and description of learning competence given by the European Commission gives us every right to attribute it to metacognitive phenomena. Learning competence is aimed at understanding and improving one's own cognitive functions (global awareness, creativity, analytical and critical thinking, responsible decision making, problem-solving, autonomous learning skills). A person should know the strengths and weaknesses of his/her qualifications, be able to reflect critically on the purposes and aims of learning, look for available training opportunities, and also understand what forms and methods of learning are most preferable for him/her. Students with learning competence can organize their own studies, evaluate their own work and seek advice, information or support when necessary.

It has long been theoretically substantiated and empirically confirmed in science that metacognitions are an acquired quality, therefore, they can be purposefully developed. Metacognitive awareness is formed in the process of acquiring educational experience, that is, knowledge of one's individual abilities and limitations, the ability to evaluate them, track the course of one's intellectual activity, adjust it as necessary, and also consciously formulate cognitive goals and strategies (Flavell, 1979; Kholodnaya, 2002; Kashapov, 2012). Metacognitive processes initiate and complete cognitive activity, and in case of difficulties, in situations of uncertainty or high responsibility, they are actively included in activities as independent components (Roberts and Erdos, 1993). Our work allows us to clarify the features of the development of various metacognitive phenomena in the student population.

It is important to understand that not all educational and cognitive activities contribute to the formation of metacognitions. Thus, Skvortsova, (2005) found in her study that the basic professional education of teachers does not determine the level of development of their metacognitive characteristics. We believe that the development of metacognitive competence is a direct consequence of the variety of forms of learning that students use, gaining experience of successes and failures in a wide variety of activities.

Our results show that the experience of additional education in nonformal and informal forms is closely related to the metacognitive and reflective competence of students. There is every reason to believe that it is here that the skills to analyse and regulate one's own cognitive processes are developed and improved. The highest level of such regulation is the awareness of their own cognitive needs, building their educational trajectory that takes into account the cognitive potential of an individual, its leading motives, as well as the requirements and limitations of the external environment.

It is necessary to consider the problem of the inclusion in the self-regulation of learning everyday (implicit) students' ideas about the possibility of changing personality and intelligence in the educational process. New evidence has been obtained that LLL-oriented students are distinguished by their internal conviction in the possibility and necessity of "working on themselves," improving their personal qualities. It is interesting that a sample of students with high learning activity demonstrated a rather critical assessment of their educational effectiveness. Kornilova et al. (2008) found that the self-esteem of inclusion in the educational process negatively correlates with the level of independence, that is, students motivated for learning and acquisition of mastery recognize the inadequacy of their own activity in the organization of learning, their dependence on its externally determined structure. On the contrary, students who highly value their efforts and results easily accept the position of "followers" in their learning. These observations explain our results.

Let us pay special attention to one of the varieties of motivation of students, namely the desire to bring public benefit. This motive is important as an element of the professional position of future lawyers. In addition, the motivation to bring public benefit reflects the opportunities of LLL to integrate an individual into the social space. Milman (2005) considers this motive "the highest aspiration in a person" and notes that the ratio of progressive and regressive motivation depends on age and the level of professional 
development. Our work shows that this motivation prevails in the group of LLL-oriented students, which confirms the social significance of LLL.

Previous studies have shown that life-long learning requires personal characteristics such as selfdirection (Candy, 1991), self-development, a focus on learning and openness to new experience (London and Smither, 1999), resilience, resourcefulness and reflectiveness (Claxton, 2000), self-efficacy, internal locus of control, cognitive abilities, self-monitoring and public self-consciousness (Sessa and London, 2006). These data are confirmed by the obtained empirical results, the significance of meta-cognitive competencies and their gradual formation in the learning process are shown.

The study confirms the high level of self-efficacy of LLL-oriented students. We know that belief in the effectiveness of one's actions significantly affects a person's behaviour: it determines the level of his activity, the complexity of the tasks and the level of goals, perseverance in overcoming difficulties, and a general life scenario. High self-efficacy is directly related to high achievement and social integration (Schwarzer et al., 1996). The obtained result can be interpreted in two ways. On the one hand, it is obvious that the level and quality of education increases the students' self-esteem and realization of their competence. On the other hand, the situation of learning something new is often associated with the risk to the individual. These risks are justified in the works of Field (2012), because LLL requires greater selfefficacy, that is, belief in one's abilities and strengths in order to achieve positive life changes.

\section{Conclusions}

LLL orientation of students is determined by a number of criteria, primarily the regular use of various methods of formal, informal and independent learning, aimed at expanding and improving their professional and life competencies. It is also important to understand the benefits of the experience gained in different areas of life, to form positive and flexible (adaptive) educational prospects. About $45 \%$ of the law students surveyed meet these criteria.

Students with high learning activity have a number of characteristic differences that can be considered markers of the LLL orientation: a high level of metacognitive knowledge and metacognitive activity, reflective competence (at the cognitive, metacognitive and personal level), internal involvement in educational activity, focus on acquiring professionalism and personal development, general self-efficacy, the prevalence of progressive and creative motives over consumer ones. The analysis showed that LLL orientation is associated not so much with academic performance and general cognitive abilities as with metacognitive characteristics and personal qualities of students.

Learning competence is a metacognitive phenomenon. This is an important psychological formation, which is formed in the course of active and diverse learning activity corresponding to the motivational orientation of students. In the process of studying at a university, students detail their cognitive needs, increase their general cognitive activity and increase their selectivity in the methods of obtaining knowledge. The experience of various learning activities and the accompanying changes in the cognitive sphere initiate the process of developing the ability to learn and form the "competence to acquire and renew competencies". In addition, there are qualitative shifts in reflection aimed at one's own cognitive processes. At the same time, it is difficult for most students to independently design their own educational trajectory that goes beyond formal education.

During training at the university, students need competent external guidance and targeted pedagogical interventions that develop metacognitive competencies (sophistication in choosing various forms of learning, analysis and assessment of their impact on their cognitive functions), which, in turn, ensure the successful development of LLL competencies.

\section{Acknowledgements}

Authors are grateful to all participants of the research (students from Odesa State University of Internal Affairs, Kyiv University of Law of the National Academy of Sciences of Ukraine and Dnipro State University of Internal Affairs) and to editorial team for their patience, kind and professional assistance.

\section{Conflict of interests}

The authors declare no conflict of interest. 
Volodymyr L. G. et al. (2020). Cognitive and metacognitive aspects of the development of lifelong learning competencies in law students, International Journal of Cognitive Research in Science, Engineering and Education (IJCRSEE), 8(2), 1-14

\section{References}

Aspin, D. N., Chapman, J., Evans, K., \& Bagnall, R. (Eds.). (2012). Second international handbook of lifelong learning (Vol. 26). Springer Science \& Business Media. http://dx.doi.org/10.1007/978-94-007-2360-3

Barros, R. (2012). From lifelong education to lifelong learning. Discussion of some effects of today's neoliberal policies. European journal for Research on the Education and Learning of Adults, 3(2), 119-134. https://doi.org/10.3384/ rela.2000-7426.rela0071

Bochelyuk, V. Y. (2020). The formation of professional and life competences in the concept of lifelong learning: psychologists' experience. Visnik HNPU imeni G.S. Skovorodi Psihologija, 61, 8-39. https://doi.org/10.34142/23129387.2019.61.01

Bochelyuk, V., \& Panov, M. (2020). Professional reorientation and retraining as an implicit re-course from the development crises of the adult age. Psychology and Personality, 17(1), 21-42. https://doi.org/10.33989/2226-4078.2020.1.195227

Bogavac, D., \& Đukić, T. M. (2017). Non-formal education within the function of responsible parenting. International Journal of Cognitive Research in Science, Engineering and Education, 5(1), 31. https://doi.org/10.5937//JCRSEE1701031B

Candy, P. C. (1991). Self-Direction for Lifelong Learning. A Comprehensive Guide to Theory and Practice. Jossey-Bass, 350 Sansome Street, San Francisco, CA 94104-1310. https://doi.org/10.5860/choice.29-4017

Claxton, G. (1999). Wise up: The challenge oflifelonglearning(pp.38-57). London:Bloomsbury. https://eric.ed.gov/?id=ED437506

Commission of The European Communities. (2000). A Memorandum on Lifelong Learning. Brussels. https://arhiv.acs.si/ dokumenti/Memorandum_on_Lifelong_Learning.pdf

Craig, G. J., \& Baucum, D. (2002). Human Development. Ninth Edition. NJ: Prentice Hall.

Delors, J. (1996). Learning: the treasure within (report to UNESCO of the International Commission on Education for the Twenty-first Century). Paris: UNESCO Publishing. https://unesdoc.unesco.org/ark:/48223/pf0000109590

Desjardins, R., \& Schuller, T. (2006). Measuring the effects of education on health and civic engagement: Proceedings of the Copenhagen Symposium. Denmark: Danish University of Education. Copenhagen: OECD. http://www.oecd.org/ education/innovation-education/37437718.pdf

European Commission. (2018). Proposal for a Council Recommendation on Key Competences for LifeLong Learning. Brussels. https://eur-lex.europa.eu/legal-content/EN/TXT/PDF/?uri=CELEX:52018SC0014\&from=EN

Eurostat (2016). Classification of learning activities. Manual - 2016 edition. Luxembourg: Publications Office of the European Union. https://doi.org/10.2785/874604

European Parliament, \& Council of the European Union (2006). Recommendation of the European Parliament and the Council of 18 December 2006 on key competencies for lifelong learning. Brussels: Official Journal of the European Union, 30(12), 2006. http://data.europa.eu/eli/reco/2006/962/oj

Faure, E., Herrera, F., Kaddoura, A. R., Lopes, H., Petrovski, A. V., Rahnema, M., \& Ward, F. C. (1972). Learning to Be: The World of Education Today and Tomorrow. Paris: UNESCO. https://unesdoc.unesco.org/ark:/48223/pf0000001801

Field, J. (2012). Is Lifelong Learning Making a Difference? Research-Based Evidence on the Impact of Adult Learning. In: D. N. Aspin, J. D. Chapman, K. Evans, R. Bagnall (Eds.), Second International Handbook of Lifelong Learning (pp. 887-897). Dordrecht: Springer. https://doi.org/10.1007/978-94-007-2360-3_54

Flavell, J. H. (1979). Metacognition and cognitive monitoring: A new area of cognitive-developmental inquiry. American Psychologist, 34(10), 906-911. https://doi.org/10.1037/0003-066X.34.10.906

Hammond, C., \& Feinstein, L. (2006). Are those who flourished at school healthier adults? What role for adult education? Wider Benefits of Learning Research Report No. 17]. Centre for Research on the Wider Benefits of Learning. http:/l www.crystaladventures.co.nz/ACE/research/WiderBenefitsofLearningResearchReportNo17ver.pdf

Kashapov, M. M. (2012). Cognitive and metacognitive understanding of the structural dynamic characteristics of creative professional thinking. In: M. M. Kashapov, Yu. V. Poshekhonov (Eds.), Creative activity of a professional in the context of cognitive and metacognitive approaches (pp. 35-121). Yaroslavl: Yaroslavl State University.

Kautz, T., Heckman, J. J., Diris, R., Weel, B., \& Borghans, L. (2014). Fostering and Measuring Skills: Improving Cognitive and Non-cognitive Skills to Promote Lifetime Success, OECD Education Working Papers, No. 110, OECD Publishing, Paris, https://doi.org/10.1787/5jxsr7vr78f7-en.

Keegan, R. (1982). The evolving self: Problem and process in human development. Cambridge: Harvard UP. https://openlibrary. org/books/OL4261074M/The_evolving_self

Kholodnaya, M. A. (2002). Psychology of Intelligence: The Paradoxes of Research. $2^{\text {nd }}$ ed., Rev. and add. St. Petersburg: Peter. http://www.ipras.ru/cntnt/rus/media/on-layn-bibliote/knigi1/holodnaya_1.html

Kornilova, T. V., Smirnov, S. D., Chumakova, M. V., Kornilov, S. A., \& Novototskaya-Vlasova, E. V. (2008). Modification of C. Dweck's questionnares in the context of students' academic achievements study. Psikhologicheskii Zhurnal, 29(3), 86-100. https://istina.msu.ru/publications/article/813115/

Lengrand, P. (1970). An Introduction to Lifelong Education. Paris: UNESCO. https://unesdoc.unesco.org/ark:/48223/ pf0000150113

London, M. (Ed.) (2011). The Oxford Handbook of Lifelong Learning. New York: Oxford University Press. https://doi.org/10.1093/ oxfordhb/9780195390483.013.0013

London, M., \& Smither, J. W. (1999). Empowered selfidevelopment and continuous learning. Human Resource Management: Published in Cooperation with the School of Business Administration, The University of Michigan and in alliance with the Society of Human Resources Management, 38(1), 3-15. https://doi.org/10.1002/(SICI)1099-050X(199921)38:1<3::AIDHRM2>3.0.CO;2-M

Mack, O., Khare, A., Kramer, A., \& Burgartz, T. (Eds.) (2016). Managing in a VUCA World. Cham: Springer International Publishing. https://doi.org/10.1007/978-3-319-16889-0

Milman, V. E. (2005). Motivation for creativity and growth: structure. Diagnostics. Development: theoretical, experimental, and applied research on the dialectics of creation and consumption. Moscow: Mireya and Co. https://www.studmed.ru/ milman-ve-motivaciya-tvorchestva-i-rosta-struktura-diagnostika-razvitie 9b7c1736385.html

Mukhordova, O. E., \& Shreiber, T. V. (Eds.) (2011). Progressivnye matritsy Ravena: metodicheskie rekomendatsii [Raven Progressive Matrices: guidelines]. Izhevsk: Udmurtskiy universitet. http://elibrary.udsu.ru/xmlui/bitstream/ 
Volodymyr L. G. et al. (2020). Cognitive and metacognitive aspects of the development of lifelong learning competencies in law students, International Journal of Cognitive Research in Science, Engineering and Education (IJCRSEE), 8(2), 1-14

handle/123456789/6542/201120.pdf

Popovic, G., Erić, O., Stanić, S., \& Krajisnik, M. (2019). Education, technological changes and economic development of Bosnia and Herzegovina. International Journal of Cognitive Research in Science, Engineering and Education, 7(2), 77-86. https://doi.org/10.5937/IJCRSEE1902077P

Raven, J. (2002). Competence in modern society: identification, development and implementation. J. Raven.-M.: Kogito Center. https://www.studmed.ru/raven-dzh-kompetentnost-v-sovremennom-obschestve-vyyavlenie-razvitie-irealizaciya_6a5ac27bfce.html

Raven, J. K., Raven, D., \& Kurt, D. (1997). A guide to progressive Raven matrices and vocabulary scales. Section 1. General part of the manual: practical guide. Moscow: Kogito-Center.

Roberts, M. J., \& Erdos, G. (1993). Strategy selection and metacognition. Educational Psychology, 13(3-4), 259-266. https:// doi.org/10.1080/0144341930130304

Savchenko, O. V. (2016). Reflexive competence: diagnostic methods and procedures. Kherson: EP Vyshemirsky V. S. https:// pj.journal.kspu.edu/index.php/pj/article/view/649

Savchenko, O. V., Aleksandrova, O. G., \& Oliynyk, N. O. (2017). The metacognitive level of organization of the personality's reflective activity. Dnipropetrovsk National University Bulletin. Psychology Series, 23(9/1), 99-108. http://dx.doi. org/10.15421/10172301

Schuller, T., Preston, J., Hammond, C., Bassett-Grundy, A., \& Bynner, J. (2004). The Benefits of Learning: the impacts of formal and informal education on social capital, health and family life. London and New York: Routledge Falmer. https://doi. org/10.4324/9780203390818

Schwarzer, R., Erusalem, M., \& Romek, V. G. (1996). Русская версия шкалы общей самоэффективности Р. Шварцера и М. Ерусалема. [The Russian version of the scale of general self-efficacy by R. Schwarzer and M. Erusalem]. Иностранная психология, 7, 71-77. http://www.romek.ru/ru/node/31

Serbin, O., \& Kulyk, Y. (2019). Professional Development of Librarians due to the Necessity of Qualitative Changes of the Branch. Ukrainian Journal On Library And Information Science, 3, 56-70. http://dx.doi.org/10.31866/2616-7654.3.2019.169668

Sessa, V., London, M. (2006). Continuous Learning in Organizations. New York: Psychology Press, https://doi. org/10.4324/9781315820941

Siarova, H., Sternadel, D., \& Mašidlauskaitè, R. (2017). Assessment practices for 21st century learning: review of evidence: NESET // report. Luxembourg: Publications Office of the European Union. https://doi.org/10.2766/71491

Skvortsova, Yu. V. (2005) Metacognitive components of the pedagogical thinking of a higher school teacher. PhD thesis. Yaroslavl: Yaroslavl State University named after P. G. Demidov. http://nauka-pedagogika.com/psihologiya-19-00-07/ dissertaciya-metakognitivnye-komponenty-pedagogicheskogo-myshleniya-prepodavatelya-vysshey-shkoly

Symonchuk, O. V. (2000). Interprofessional mobility and change of the social identity. PhD abstract thesis. Kyiv: Institute of Sociology National Academy of Sciences of Ukraine http://base.dnsgb.com.ua/files/ard/2000/00sovzsi.pdf

Tychyna, I. M. (2013). Substantive aspects of value strategies of personal self-realization in the process of changing profession. Pedagogical education: theory and practice. Psychology. Pedagogy, 19, 86-91. http://nbuv.gov.ua/UJRN/ Potip_2013_19_26

United Nations. (2015). Transforming ourWorld: The 2030Agenda for Sustainable Development. https://sustainabledevelopment. un.org/post2015/transformingourworld 